\title{
Sønderjyske billeder
}

- en billedsamling og dens muligheder

\section{af Henrik Fangel}

Historiske Samlinger for Sønderjylland i Aabenraa er landsdelens største samling af fotografisk materiale. Samlingen blev grundlagt omkring 1960 af landsarkivar Peter Kr. Iversen, som også varetog opbygningen gennem mere end to årtier. Under Henrik Fangels ledelse siden 1985 foregik der en imponerende udvikling. Inden sin alt for tidlige død nåede Henrik Fangel at udarbejde en redegørelse for samlingernes indhold. Han fortæller her om de ca. 200.000 billeder, bl.a. om de mange negativsamlinger. Billederne er et meget rigt kildemateriale til studier af landsdelens topografi, dens nationale, politiske og økonomiske historie og personalhistorie.

\section{Samlingernes etablering}

Institut for Sønderjysk Lokalhistorie er en selvejende institution med hjemsted i Aabenraa. Den bygger på en ca. 30 år gammel institution, Historiske Samlinger for Sønderjylland, som igen er et barn af Historisk Samfund for Sønderjylland.

I slutningen af 1950erne havde Historisk Samfund for Sønderjylland spredt og lejlighedsvis foretaget indsamling af billeder og traditionsstof fra Sønderjylland. Dette arbejde aktiveredes stærkt $i$ efteråret 1960, ikke mindst gennem Historisk Samfunds formand, landsarkivar Peter Kr. Iversens indsats. Der blev især taget fat på optagelse af lydbånd med fremtrædende sønderjyske personligheder. En del billedmateriale var i tidens løb afleveret til Landsarkivet, og alt dette materiale blev nu samlet i Lokalhistorisk Samling for Sønderjyllland, der i 1968 blev udskilt fra Historisk Samfund for Sønderjylland som en selvejende institution med sin egen bestyrelse. Den fik nu navnet Historiske Samlinger for Sønderjylland. Driftsmidler skaffedes ved tilskud, især fra Dansk Kultursamfund og siden 1970 fra Sønderjyllands amtskommune. I 1974 kunne samlingerne rykke ind i egne lokaler i stueetagen i den gamle, men nyindrettede arkivbygning på Landsarkivet. Her har samlingen stadig til huse og disponerer over tre kontorlokaler, et stort arkivrum samt Landsarkivets atelier og mørkekammer.

I årene 1964-82 blev registrering og ordning varetaget af fru Vibeke Gribsvad under landsarkivar Peter Kr. Iversens tilsyn. Det skyldes ikke mindst hendes omhyggelige og ihærdige arbejde, at billedsamlingen er registreret på kartotekskort, således at der kan søges via et kartotek og ikke via billederne selv. 


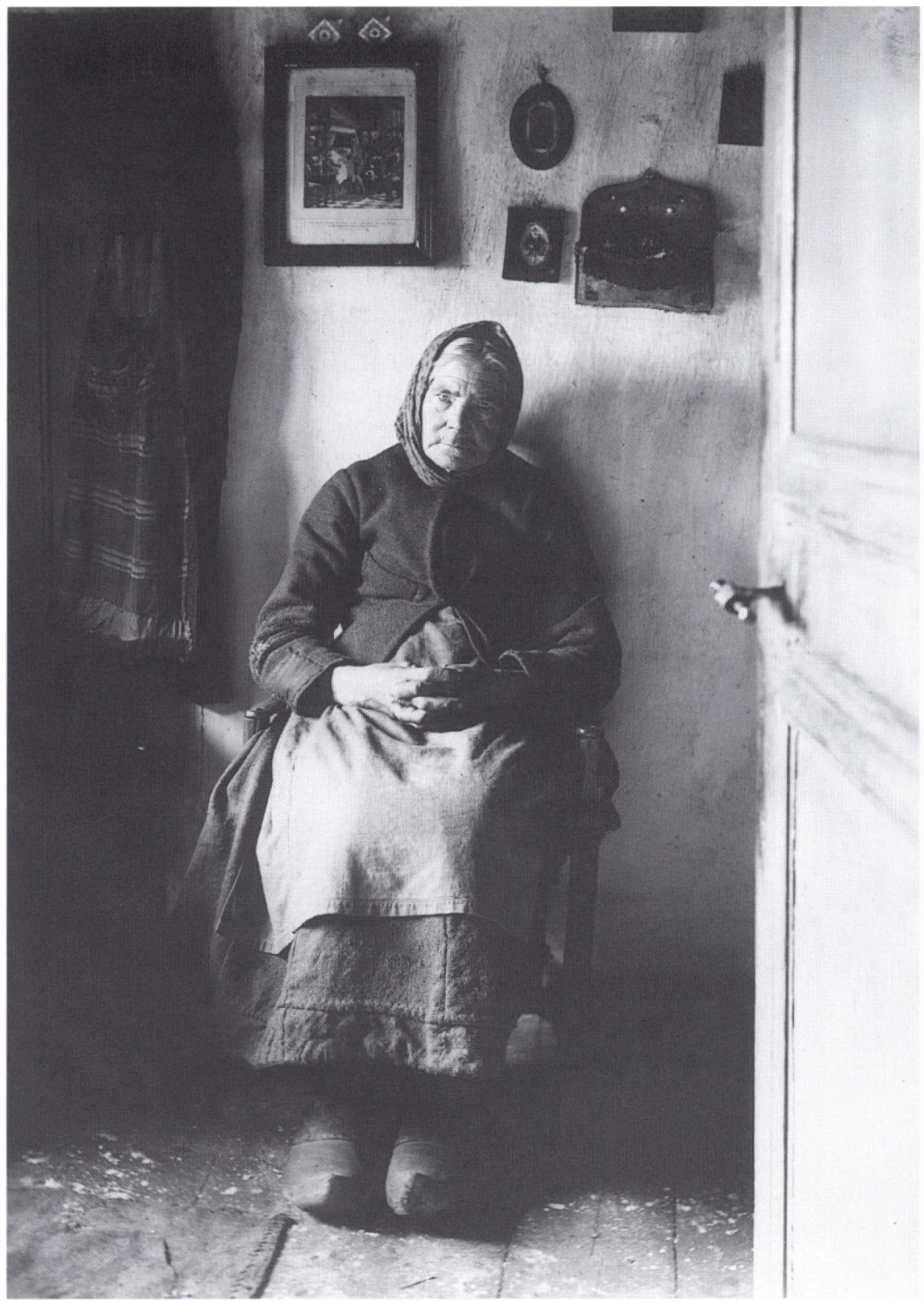

Foruden at vare en habil portrattegner var godsinspektor H. C. Davidsen pa Schackenborg slot ogsa en dygtig fotograf. Han har efterladt sig en samling glasnegativer fra egnen omkring Mogeltonder, dels med topografiske motiver, dels med personer, isar aldre mennesker, fotograferet $i$ en stue eller foran et hus. Disse billeder af krogede, slidte mennesker er af en helt sarlig karakter. Her er det Stine Kniffs i Mogeltonder, der er fotograferet i 1913. Kopi af glasneg. nr. 69-122 (13×18). 
I 1974 blev billedsamlingen forøget ganske betydeligt, idet Aabenraa byhistoriske Forenings store Aabenraa-billedsamling blev deponeret i Historiske Samlinger, der herefter varetog opbevaring og registrering af Aabenraa-billeder på linje med den øvrige billedsamling. I dag er Aabenraa byhistoriske Forenings samling en integreret del af institutionen, der således også fungerer som lokalarkiv for Aabenraa, for så vidt angår billedmæssig dokumentation.

Helt fra begyndelsen omkring 1960 var det et stærkt ønske at få knyttet en videnskabelig uddannet medarbejder til Historiske Samlinger. Foruden at være leder af samlingerne skulle han eller hun fungere som konsulent for det lokalhistoriske arbejde i Sønderjylland. Man erkendte allerede dengang, at der var behov for hjælp og vejledning for de små lokale samlinger, som var ved at dukke op. Landsarkivets personale udførte i nogen grad dette arbejde som et led $\mathrm{i}$ arkivets udadvendte oplysningsarbeje, men da der i løbet af 1960erne og især i 1970erne opstod et meget stort antal lokalhistoriske arkiver og foreninger, voksede behovet for en sådan konsulent.

En forudsætning for oprettelsen af denne stilling var imidlertid stærkt forøgede bevillinger. Forhandlinger med amtskommunen førte i 1985 til, at amtet forhøjede sit tilskud, således at der fra 1. august 1985 kunne ansættes en leder.

Da Historiske Samlingers virkeområde således blev udvidet, vedtog bestyrelsen på sit møde den 22 . november 1985 at ændre institutionens navn til »Institut for Sønderjysk Lokalhistorie«. Man fandt, at dette navn var mere dækkende for det virkeområde, som nu er institutionens. Instituttet har ifølge sine vedtægter følgende opgaver:

1) at bestyre billed-, bånd- og filmsamlingen, som efterhånden er af ganske betydeligt omfang,

2) at fungere som konsulent, ikke alene for de lokalhistoriske samlinger, arkiver og foreninger $i$ landsdelen, men også for enkeltpersoner, der arbejder med sønderjysk historie,

3) at fungere som forskningsinstitution med forskning inden for sønderjysk historie som sit forskningsfelt.

I det følgende vil billedsamlingen blive gjort til genstand for en nærmere omtale.

\section{Billedsamlingens opbygning og omfang}

Det er vanskeligt at opgøre helt præcist, hvor mange billeder - så vel negativer som positiver - billedsamlingen omfatter i dag, men med et forsigtigt skøn 
kan samlingens omfang anslås til ca. 200.000. Heraf udgør to fuldstændige negativarkiver fra et par fotografer ca. halvdelen.

Denne store samling er skabt gennem en blanding af passiv og aktiv indsamling. En meget stor del af positiverne er indkommet gennem tilfældige afleveringer. En del af negativsamlingerne er derimod tilvejebragt ved en aktiv indsats, ligesom der er indkøbt kopier af negativer i andre samlinger, bl.a. Museet på Sønderborg slot og Det kongelige Bibliotek.

Alt ialt er der registreret 1500 afleveringer $\mathrm{i}$ årene 1961-90. Disse afleveringer omfatter ikke kun billeder, men også afleveringer til instituttets samling af lokale tryk, især af sang- og salmebøger, skolebøger mv. Antallet af afleveringer har $\mathrm{i}$ de sidste fem år svinget mellem $77 \mathrm{og} 108$. De enkelte afleveringer omfatter fra et enkelt til flere tusinde billeder. En del af afleveringerne er registreret som affotograferinger af billeder, som er lånt med henblik på kopiering. Der er i årenes løb til stadighed foretaget affotograferinger af billeder i samlingen, således at instituttet i dag er besiddelse af en samling på ca. 8000 negativer (format $24 \times 36 \mathrm{~mm}$ ). Dette er naturligvis af stor sikkerhedsmæssig betydning, men set i forhold til billedsamlingens samlede omfang er det kun max. $10 \%$ af alle positiver, der således er sikkerhedskopieret.

\section{Billedsamlingens indhold}

Samlingerne er systematisk opdelt og omfatter

1) en topografisk samling, opbygget efter købstad, flække og sogn; postkortene udgør en væsentlig del af den topografiske samling, som også omfatter fotografier, der ikke indgår i en særsamling.

2) en samling af portrætter og fotografier af enkeltpersoner; hertil hører en såkaldt familiesamling, dvs. samlinger af personbilleder, der ikke kan indordnes efter personnavn, men hvor familien må være det overordnede princip. Denne samling rummer mange portrætalbums, således som de var i anvendelse fra slutningen af 1800 -årene.

3) en sagligt opbygget samling, især omfattende gruppebilleder; hertil hører også den kronologisk opbyggede samling, der bl.a. omfatter billeder fra de to verdenskrige, fra genforeningen, fra møder og forsamlinger, forskellige begivenheder $\mathrm{mm}$.

4) særsamlinger, omfattende billeder, der hører naturligt sammen, f.eks. en bestemt fotografs billeder, eller billeder, der set ud fra et proveniens-princip udgør en enhed. Til denne afdeling hører bl.a. de omfattende negativsamlinger, men også en række samlinger af postkort, ordnet efter postkort- 


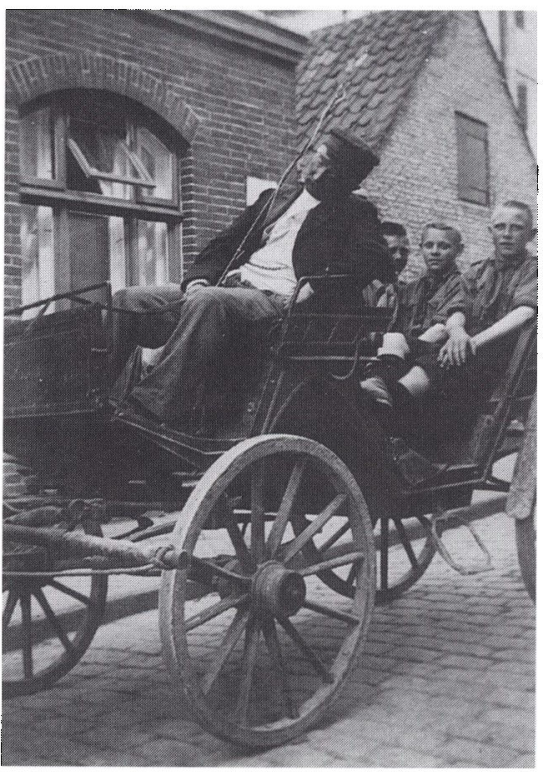

Disse tre billeder viser at politisk og national historie kan fortalles på mange måder.

Øverst t.v.: Tusinder af mennesker drog til Sonderjylland $i$ genforeningsdagene $i$ juli 1920. Her er det Nanna Hansen fra Artillerivej 48 i Kobenhavn, der har "skudt" "En overanstrengt Droskekusk paa Gaden i Sonderborg 11/7", dvs. den dag da den store genforeningsfest blev holdt $i$ Kongeskansen på Dybbøl. Amatørbillede, sarsaml. 31029.

Øverst t.h.: Valget den 3.april 1939 blev $i$ Sonderjylland et opgor med det nu helt nazificerede, hjemmetyske parti "Slesvigsk parti", der var overbevist om at dagen var kommet for Nordslesvigs tilbagevenden til det tyske rige. Slesvigsk Parti fik kun ca. $15 \%$ af stemmerne og valgdeltagelsen var over $90 \%$. Redaktor Morten Kamphovener tog dette billede $i$ Aabenraa med valgere på vej til og fra valglokalet i Nygadeskolen $i$ baggrunden og det tyske bibliotek $i$ huset til højre. Morten Kampheveners negativer findes $i$ instituttets samlinger.

Nederst: Mange af billederne i det tyske mindretals billedsamling er taget af Rudolf Gimm i Bolderslev, bl.a. dette motiv fra 1943. Det viser en gruppe tyske drenge, der fra tyske storbyer blev sendt pa ferie $i$ det fredelige Nordslesvig. De boede på Knivsbjerg, og her er nogle af drengene fotograferet foran Knivsbjerg-tårnet, der blev rejst i 1899. Sarsaml.nr. 301-196.
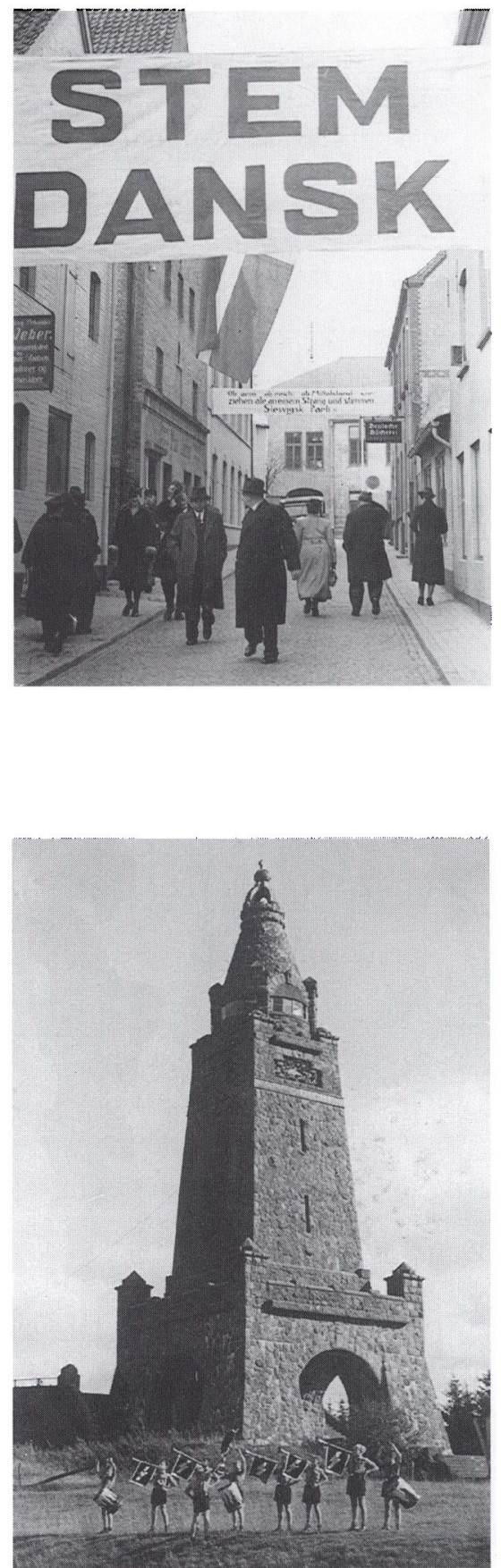
fabrikant. Mange topografiske billeder er på denne måde udskilt fra den topografiske samling. Alle billeder i særsamlingerne er forsynet med et nummer (særsamlingsnummer+løbenummer), hvilket letter såvel søgning som genanbringelse af billeder efter endt brug.

\section{Fotografarkiver og negativsamlinger}

Som næunt er instituttets negativsamlinger registreret som særsamlinger. Negativsamlingerne rummer vel ca. 120.000 negativer, hvoraf en enkelt Aabenraafotografs udgør 2/3. En meget stor del af negativerne er glasnegativer. En del er renset og opbevares i stålskabe; alle negativer opbevares i oprejst stilling.

Det er meget tilfældigt, hvad der er bevaret af sønderjyske fotografers negativarkiver, og kun ganske få er bevaret fuldstændigt. I institutet opbevares tre fuldstændige fotografarkiver, dele af to samt en lang række mindre "rester« af fotografarkiver, heriblandt en del amatører, dvs. fotografer som ikke har haft fotografiet som fast levebrød. På Haderslev Museum findes fire fuldstændige fotografarkiver samt rester af fire, i Museet på Sønderborg slot haves en fotografs arkiv samt museets egen glasnegativsamling, der omfatter dele og "rester« af forskellige ældre fotografers samlinger, ikke mindst omkring genforeningen. Tønder Museum har bevaret halvdelen af en negativsamling (i bilaget bringes en fortegnelse over alle disse fotografarkiver).

De store fotografarkiver rummer naturligvis et meget stort antal portrætter og gruppebilleder, men der er også mange topografiske motiver, optagelser fra forskellige begivenheder, kulturhistorisk interessante optagelser o.m.a. De mindre negativsamlinger rummer næsten udelukkende sådanne motiver, og er derfor af meget stor værdi.

\section{Billedsamlingens tilgængelighed}

Billedsamlingen er tilgængelig gennem det meget store seddelkartotek, der er opbygget i de samme "afdelinger« som selve samlingen. Søgninger, der går på tværs af denne opbygning vanskeliggøres dog noget af, at der er alt for få krydshenvisninger. Det gælder især den emnemæssige søgning, hvor meget skjuler sig i den topografiske afdeling. F.eks. er det meget begrænset, hvad der findes af billeder med hestekøretøjer i den sagligt opbyggede afdeling; men henvisningerne til den topografiske afdeling er få, selvom der utvivlsomt gemmer sig mange hestekøretøjer på de topografiske billeder. Søgesystemet søges løbende forbedret. En registrering på SLA’s EDB-registreringssystem Arkibas 
vil lette søgningen betydeligt, men da der skal meget store arbejdsmæssige ressourcer hertil, vil det ikke være muligt indenfor en overskuelig årrække at lette søgningen ad denne vej.

For alle særsamlinger, herunder negativsamlinger, gælder, at der er udarbejdet registraturer til hver enkelt samling, ligesom de fleste af dem er tilgængelige via seddelkartoteket.

\section{Brug af samlingen}

Billedsamlingen er i årenes løb først og fremmest blevet brugt til illustration af bøger. Ikke mindst Historisk Samfund for Sønderjylland har draget nytte af samlingen til sine bogudgivelser, ligesom foreningen har benyttet samlingerne som arkiv for de billeder, man har fremskaffet andetsteds fra. På den måde er der suppleret med bl.a. portrætter af en lang række fremtrædende sønderjyder eller personer med tilknytning til Sønderjylland, ikke mindst fra Det kongelige Biblioteks billedsamling. Men også til en lang række andre værker udgivet af forlag, institutioner og foreninger er der leveret billeder. I de seneste år har der været trukket på samlingerne i forbindelse med videoproduktioner, hvor der har været indlagt still-billeder. Også til udstillinger er der hentet billeder, ikke mindst til de udstillinger, som instituttet selv har produceret.

Denne brug og disse udlån afspejler dog kun i meget begrænset omfang de store muligheder for at belyse udviklingen i Sønderjylland gennem mere end 100 år, som billedsamlingen rummer. En påbegyndt publikationsserie "Sønderjyske billeder" antyder nogle af mulighederne, selvom disse billedhæfter ikke er bundet af samlingernes egen beholdning. Som nr. 1 i denne serie udsendtes i 1988 »H.P. Hanssen - liv og virke«, som gennem billeder fra samlingerne samt gengivelse af enkelte tryk giver et indtryk af de muligheder, der er for at belyse nationale og politiske forhold. Nr. 2 i serien, „På tur med Biehl - i Gråsten «, er det første eksempel på de muligheder, der ligger i en systematisk anvendelse af de topografiske billeder, her eksemplificeret gennem Carl C. Biehls store negativsamling. Serien »På tur med Biehl - « vil fortsætte igennem andre områder af Sønderjylland. Nr. 3, "Dansk eller tysk?« med undertitlen "Billeder af national selvforståelse i 1920« tager sit udgangspunkt i afstemningsplakater og nødpengesedler fra genforeningstiden og udkom i 1992.

I det følgende gennemgås og kommenteres en række områder, hvor billedsamlingen især er anvendelig til belysning af landsdelens fysiske, nationale og økonomiske udvikling eller sider heraf. 


\section{Topografi}

Samlingen af topografiske billeder er nok den mest omfattende del. De topografiske motiver findes dels i den topografiske samling, dels i særsamlingerne, og som det fremgår af fortegnelsen over fotografarkiver og negativsamlinger $i$ bilaget, rummer nogle af disse udelukkende topografiske motiver. Det gælder først og fremmest Carl C. Biehls samling samt en række af de mindre negativsamlinger.

Carl C. Biehl (1872-1950) var postkortfabrikant i Gråsten og modtog bestilling på levering af postkort. Han eller en betroet medarbejder tog selv ud og optog de billeder, der skulle være forlæg, og på grundlag heraf fremstilledes postkortene. Mange »nationale « motiver, som f.eks. motiver fra 1864-grænsen eller fra Dybbøl fremstillede Biehl selv og solgte for egen regning. Bevaret er foruden ca. 5000 glasnegativer ca. 5000 planfilm en samling af Biehls egne kontaktkopier af negativerne med anvisninger til bogtrykkeren om antal tryk, evt. retoucheringer, tekst på postkortene osv. Hertil kommer så - det fardige resultat - selve postkortene, der som regel er afleveret til de historiske samlinger som dele af forskellige enkeltafleveringer. Det er dog langt fra alle Biehls postkort, der findes i samlingerne, ligesom der også findes postkort, hvortil der ikke eksisterer noget glasnegativ.

Biehls negativsamling dækker hele det nuværende Sønderjylland samt et område syd for grænsen, især Angel. Efter 1920 udvidedes arbejdsområdet til også at omfatte store dele af Jylland og Fyn. Også negativerne til postkortene herfra er bevaret. Som helhed betragtet rummer Biehls samling et meget vigtigt kildemateriale til Sønderjyllands fysiske udvikling fra omkring 1900 og frem til ca. 1930. Ikke mindst forandringer i de mange mindre byer, bl.a. stationsbyerne, er godt belyst gennem denne samling, der også giver et indblik i, hvorledes postkortfremstillingen er foregået $i$ postkortets storhedstid $i$ begyndelsen af århundredet.

Også for andre af instituttets mange postkort gelder det, at de er registreret ikke efter motiv - men efter postkortfabrikant. Det gælder først og fremmest den meget store samling af postkort fra Aabenraa. Denne registreringsform forudsætter, at mulighederne for søgning på lokalitet er gode, men giver en række fordele, bl.a. med hensyn til datering. Også postkortfabrikanters kopiering af hinandens postkort kan belyses på denne måde, samtidig med at man får et indtryk af, hvorledes postkortenes mængde svinder ind. I begyndelsen af århundredet kan der hos Aabenraas største postkortfabrikant, boghandler A. Wohlenberg, optælles ca. 200 forskellige postkort (nogle af dem dog med samme motiv), mens "Jasmunds kiosker «, der fremstillede postkort ca. $1935-45$, kun er registreret med 80 forskellige kort.

Biehls samling suppleres af en række af de mindre negativsamlinger, der 


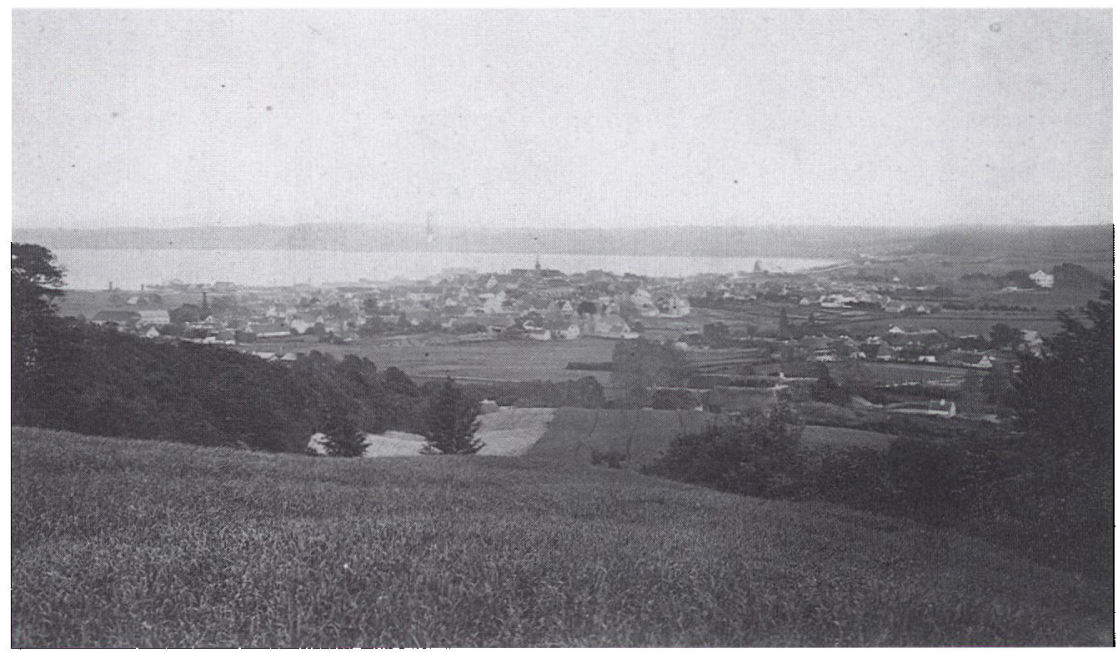

Blandt de aldste topografiske billeder $i$ instituttets samlinger er fotograf J. H. Dorrs motiver fra Aabenraa, hvoraf der er bevaret ca. 60, de aldste fra 1870erne. Dorr virkede som fotograf $i$ Aabenraa 186585. Her er det et panorama of Aabenraa set fra nordvest med landsbyen Kolstrup i forgrunden. Brundlund slot yderst til hojre og bybakken med kirketårnet midt $i$ billedet. Sarsaml. 261-35.

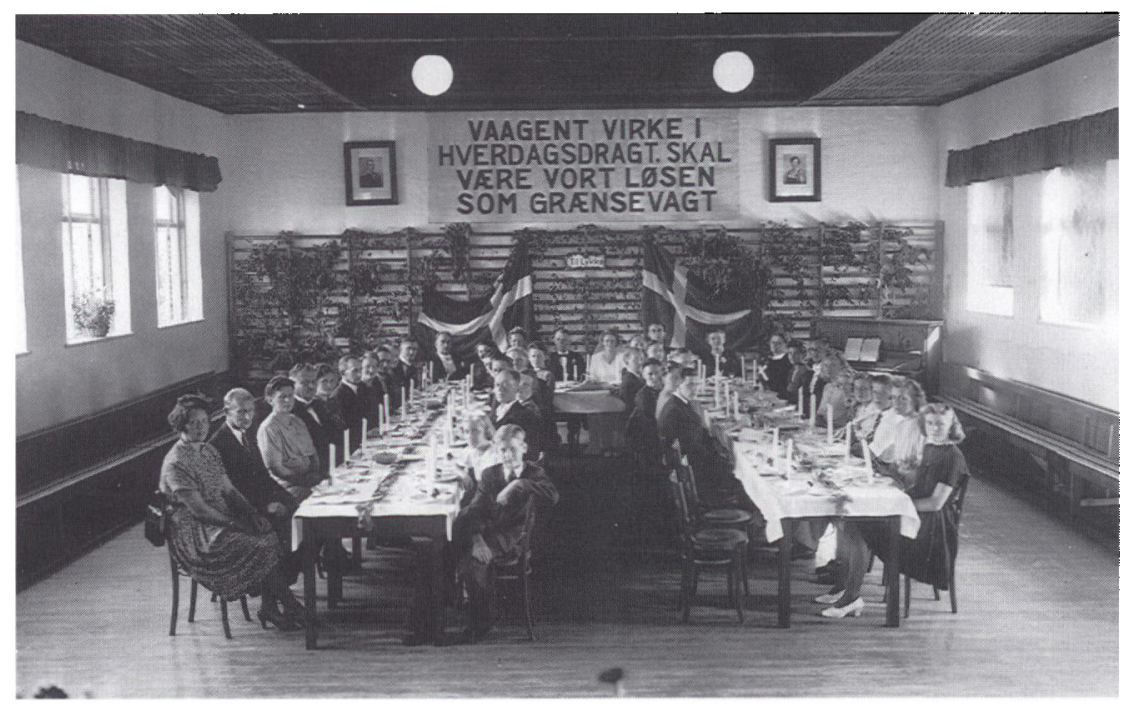

I de professionelle fotografers negativsamlinger udger portratterne hovedparten, men der findes dog også $i$ disse negativsamlinger andre motiver af stor vardi. Det gaelder bl.a. gruppebillederne, der omfatter mange forskellige grupper. Her er billeder af foreningsbestyrelser, af råd og udvalg og af personale i firmaer, her er konfirmand- og skolebilleder og her er bryllups-, solv-og guldbryllupsbilleder, som f.eks. dette, der stammer fra fotograf Clausen, Aabenraa, og viser et bryllup i forsamlingshuset $i$ Rinkenas, formodentlig engang i 1940erne. Kopi af glasneg. $\mathrm{nr} .80-222(18 \times 24)$. 


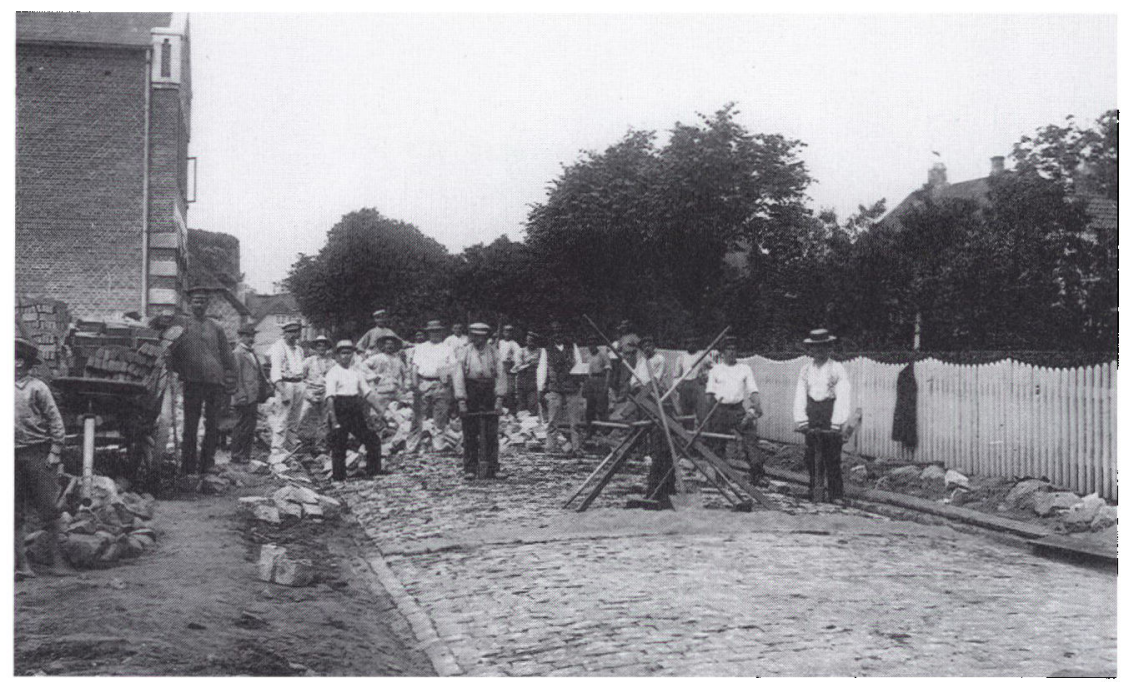

Blandt de professionelle fotografers negativer er ogsd mange topografiske motiver, som f.eks. dette fra fotograf L. Matthiesen $i$ Hojer. Et hold brolaggere er $i 1908$ igang med arbejdet. Billedet illustrerer ogsa det store forbrug af arbejdskraft, som var kendetegnende for aldre tid. Kopi af glasneg. nr. 73$4417(18 \times 24)$.

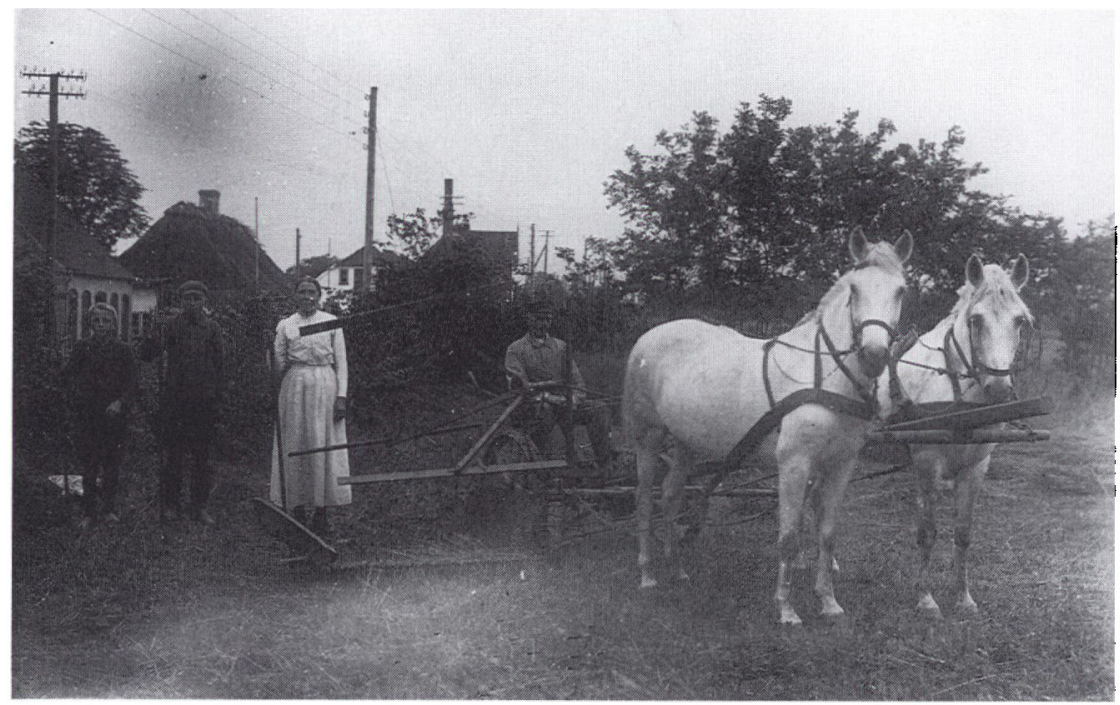

Af fotograf $W$. Schützsack, der arbejdede som fotograf i Aabenraa, Haderslev, Gram og Tinglev, er bevaret ca. 1000 glasnegativer med motiver fra Nordals, hovedsagelig gårde og huse. Blandt motiverne er dog ogsd en del arbejdsscener som feks. dette - lidt opstillede - billede fra omkring 1930. Det er fra Holm, hvor Mollegade ses i baggrunden; moderen og de to drenge er samlet ved aflaggeren, klar til at binde det hostede korn op. Kopi af glasneg. nr. 72-2198 (9×12). 


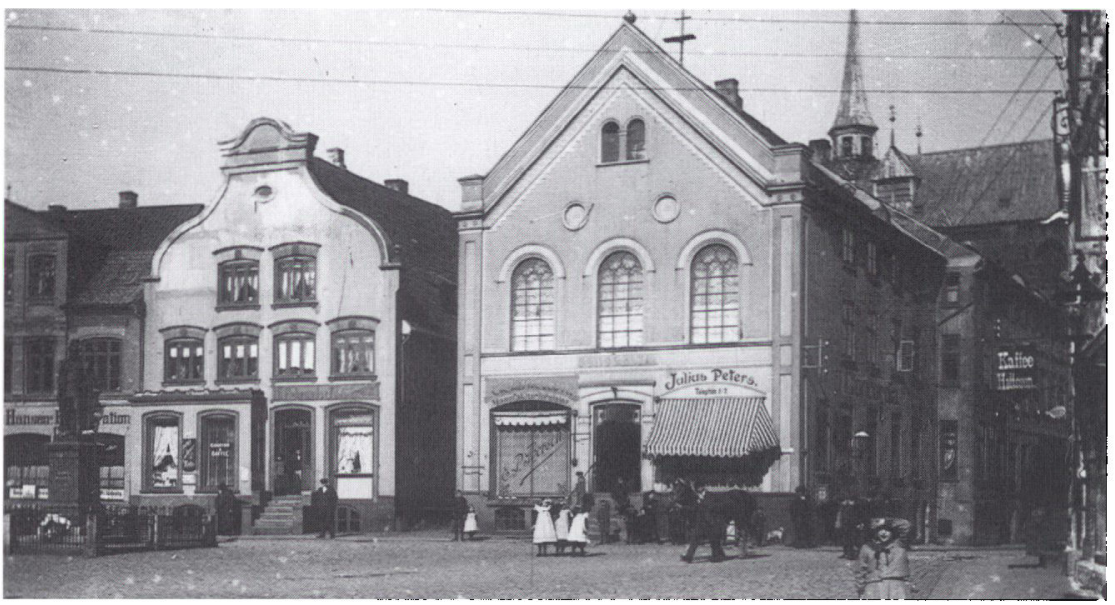

En sumling glasnegativer med motiver fra Haderslev og egnen heromkring tilskrives bogbinder Th. Münster, der var ansat hos boghandler Carl Nielsen i Haderslev. Billederne er taget bade for og efter 1920. Her er det Torvet i Haderslev, som er indfanget af fotografen en stille og solrig middagsstund i begyndelsen af århundredet. Til venstre stör stutuen af kejser Wilhelm 1., som blev rejst $i 1890$ og dakket til $i$ januar 1920, da de franske alpejagere rykkede ind $i$ byen. De skulle forskanes for synet af den kejser, under hvem Alsace-Lorraine var blevet erobret! Også denne hegivenhed er sammen med statuens nedtagning dokumenteret gennem billeder. Kopi af glasneg. nr. 75-14 (13×18).

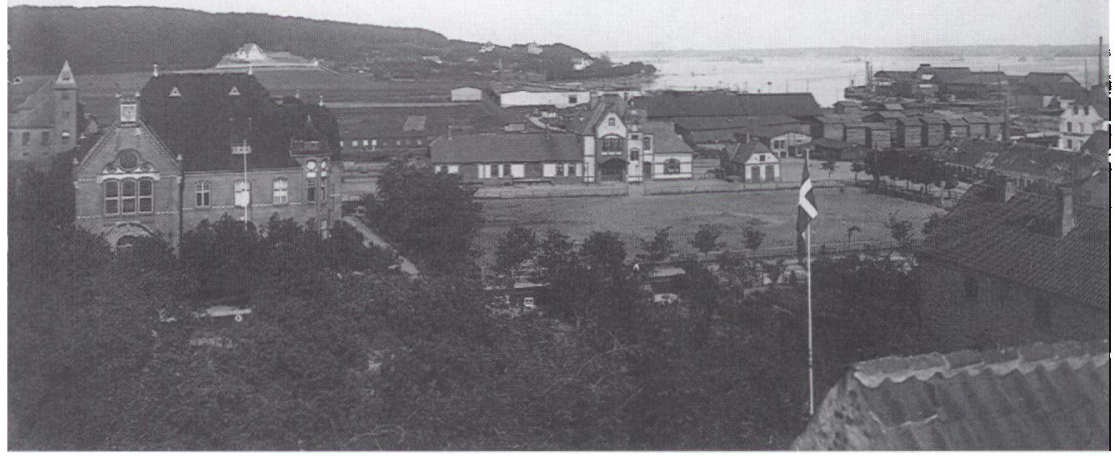

På fotograf Clausens hillede af udsigten fra den bakke, hvor Aabenraa ligger, ses den nye markedsplads med amtshuset fra 190() til venstre og amtshanegården fra 1899 i midten. Bag den ligger de såkaldte karantanestalde, hvortil al import af levende kvag fra Danmark gik for 1920. Herfra transporteredes $k$ vaget videre ud $i$ Tyskland med jernbane. Til hojre ses tommerstabler ved Gammelhavn. Billedet er imidlertid ekstra interessant, fordi man i det fjerne, ude pa fjorden, kan skimte 9-10 skibe fra den tyske flade. Hvert ar fra 1905 til 1913 afholdt skibe bla. fra den narliggende fludestation $i$ Sonderborg en såkaldt "Marinelandungsmanöver $p a ̊$ Aabenraa fjord, og disse manvvrer har sat sig spor $i$ et ikke uhetydeligt antal fotos. Kopi af glasnegativ nr. 80-09 (18×24). 


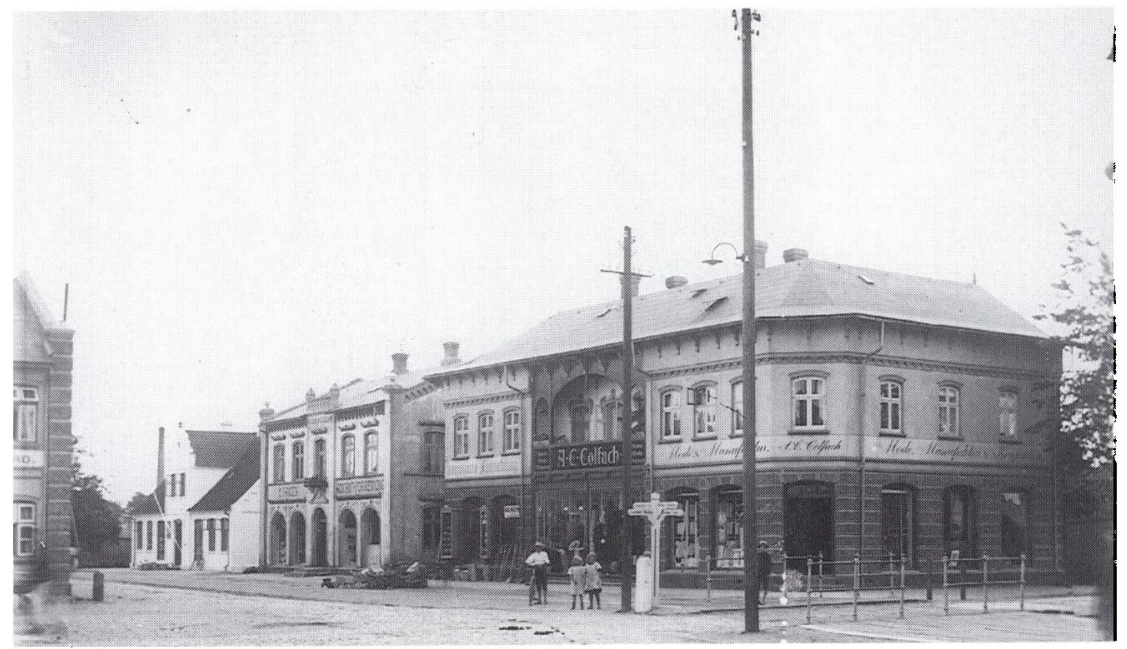

Carl C. Biehls negativer og tilhorende postkort illustrerer isar de store forandringer, som skete i årene op til 1. verdenskrig, bla. i de mange stationsbyer, der udviklede sig langs de mange smalsporede amtsbaner. På Torvet $i$ Rodding opforte manufakturhandler A.C.Colfach o. 1893 en stor ejendom ved Torvet, på hjornet af Østergade og Sdr. Alle. I ejendommen havde også en Jernvareforretning til huse og ved siden af ses $W$. Hansens »Kontant-forretning«. Det er eksempler på typer af forretninger, som voksede frem på denne tid. Rodding blev $i 1899$ endestation for amtsbaner fra Haderslev. Kopi af glasneg. $n$ r. 74-2866 (13×18).

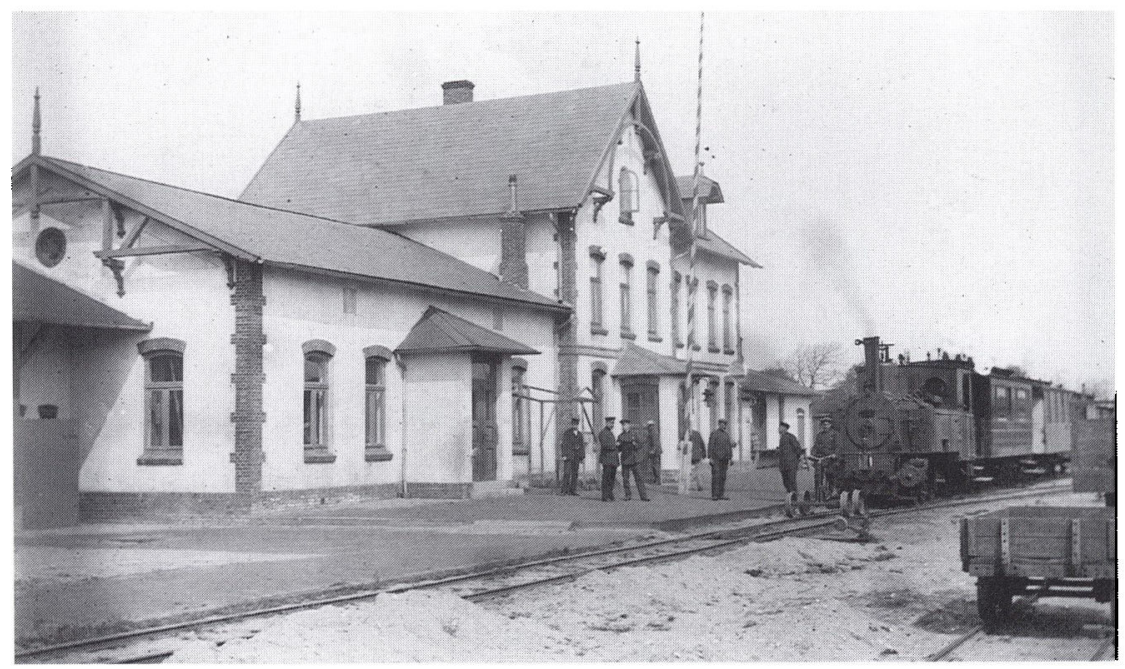

Et net af smalsporede amtsbaner anlagdes $i$ ärene 1899-1911 $i$ Haderslev, Aabenraa og Sonderborg amter og knyttede de tre amtsbyer nart sammen med deres opland. Amtsbanerne blev af vasentlig betydning for handelslivets opblomstring $i$ de tre byer $i$ disse år. Pa Carl C. Biehls billede fra Skodborg station er toget klar til afgang imod Haderslev, fot. ca. 1910. Kopi af glasneg. nr. 74-2908 (13×18). 

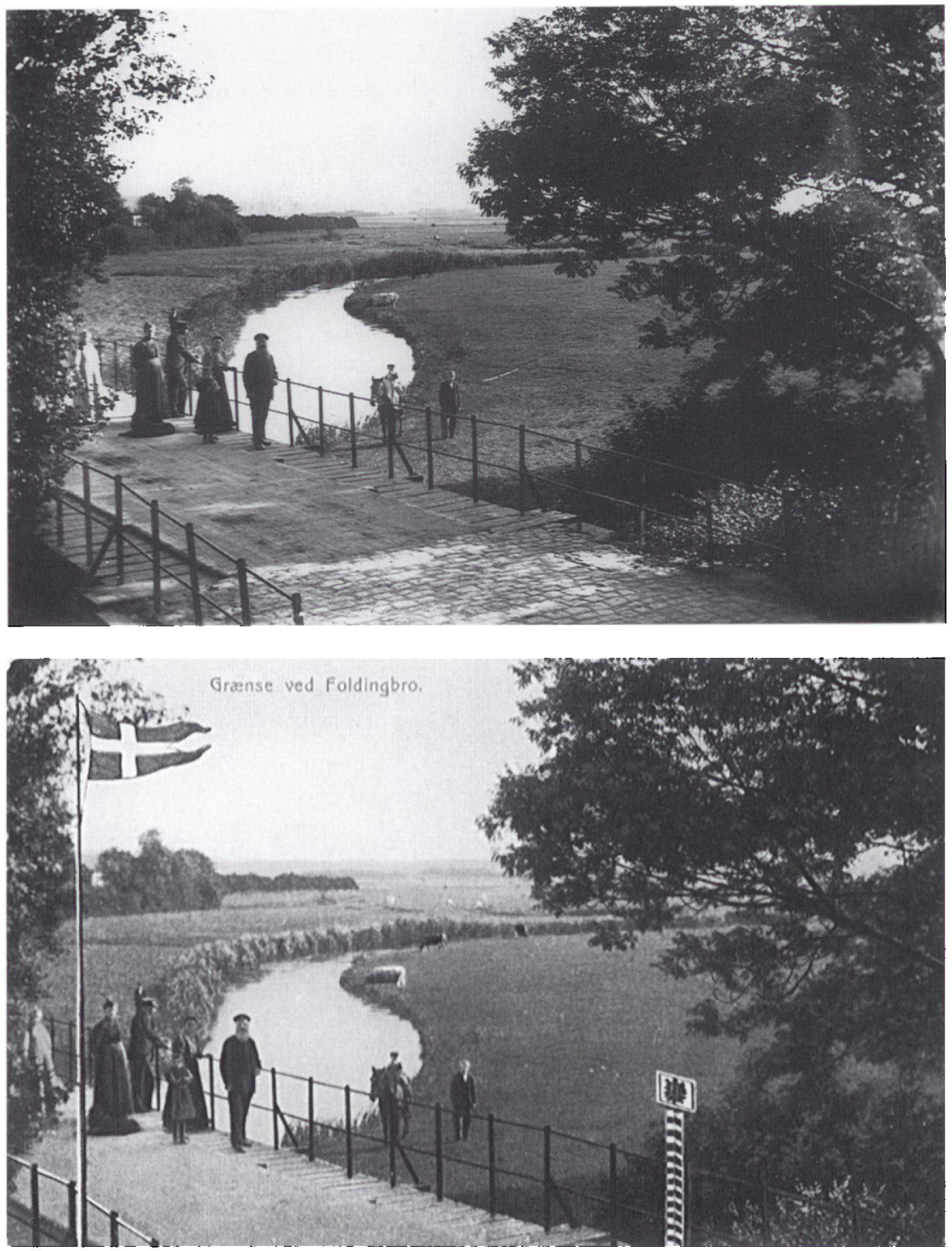

Carl C. Biehl har fremstillet mange postkort med motiv fra Kongeả-gransen, men det var ikke altid sà let at se, at der var tale om en granse. Kopien af glasnegativet herover viser blot en bro over en $\dot{d}$, der snor sig gennem landskabet. Pd det farvelagte postkort, der er fremstillet efter negativet, er det tydeliggjort, at det er gransen ved Foldingbro. Til venstre er indtegnet et vajende Dannebrog og til hejre en gransepal med den tyske orn! Postkortet signalerer nok også håbet om at se denne granse slettet. Kopi af glasneg. nr. 74-2323. Farvelagt postkort, ustemplet. 
udelukkende rummer topografiske motiver. De koncentrerer sig på Vestkysten med Th. Møllers samling fra Løgumkloster, lægen Voswinkels motiver fra Rømø og godsinspektør Davidsens fra Møgeltønder og egnen deromkring som de ældste - alle fra før 1920 og kort tid herefter. Noget yngre er A. Martinsens samling fra Højer og vestkysten iøvrigt. Fra østkysten haves W.Schützsacks billeder fra Nordals, Richard Reichs fra Augustenborg-egnen, Th. Münsters fra Haderslev-egnen samt en nyligt afleveret samling negativer med tilhørende postkort fra østkysten fra ca. 1930. Fotograf Clausens store samling fra Aabenraa rummer særdeles mange motiver fra byen og dens omegn.

Instituttets negativsamlinger rummer således et særdeles omfattende topografisk materiale, der dækker det meste af Sønderjylland. Hertil kommer så de kopier af andre negativsamlinger, som instituttet er i besiddelse af. Det gælder negativsamlingen fra Museet på Sønderborg slot, Rud.Olsens negativsamling i Det kongelige Bibliotek (forlæg for postkort) samt Sundbølls samling fra Haderslev Museum, der foreligger både i $35 \mathrm{~mm}$ positivfilm og i renegativ og ligesom Rud. Olsen omfatter det meste af Sønderjylland.

Den topografiske samling, der som nævnt omfatter alle de topografiske billeder, som ikke hører til nogen særsamling, supplerer negativsamlingerne, men det er meget tydeligt, at samlingen er af meget begrænset omfang de steder, hvor der igennem mange år har været et lokalhistorisk arkiv. Med sine mange postkort ligger den topografiske samlings tyngdepunkt i begyndelsen af århundredet. Fotografier af kirker og skoler fylder også godt op her.

Det er et generelt problem for instituttets topografiske samlinger, at materialet bliver meget mere begrænset, når vi kommer op $\mathrm{i}$ anden halvdel af det 20. årh., hvor postkortenes mængde skrumper stærkt ind. Kun for Aabenraas vedkommende kan samlingerne her dokumentere de fysiske forandringer, der er foregået, dels gennem en meget stor samling af billeder fra Aabenraa Kommunes tekniske forvaltning (fra ca. 1948 og frem), dels gennem omfattende afleveringer fra Jydske Tidendes lokalredaktion (1980erne).

I årene 1966-76 gennemførte Historiske Samlinger en gennemfotografering af gamle bygninger $\mathrm{i}$ hele det gamle Tønder amt. Det skete i samarbejde med et net af lokale kontakter samt en amatørfotoklub i Tønder og gav som resultat en meget omfattende samling negativer, der dokumenterer et stort antal af egnens ældre gårde og huses udseende på denne tid.

Endelig skal det nævnes, at amtskommunen for nylig har deponeret en stor samling dias, optaget fra luften, af hele Sønderjylland i forbindelse med regionalplanens udbejdelse i slutningen af 1970erne. Der er optagelser af alle bebyggelser i Sønderjylland i denne værdifulde samling. 


\section{Portrcetter og familiesamlinger}

Samlingen af portrætter af enkeltpersoner er meget omfattende, men noget tal for, hvor mange personer der haves mindst et portræt af, kan ikke gives. Man kan dog regne med, at alle mere kendte og fremtrædende sønderjyder inden for nationalt og politisk arbejde de sidste ca. 100 år er repræsenteret, mens det måske nok er knap så sikkert, om det samme kan siges om erhvervslivets repræsentanter. Her yder de nævnte fotografnegativsamlinger dog et væsentligt bidrag.

Blandt familiesamlingerne stammer den største enkeltsamling fra Thoma Jacobsen, der tilhørte en fremtrædende Aabenraa-slægt. Samlingen omfatter ikke mindre end 11 albums med adskillige hundrede billeder, en stor del identificerede. Et meget bredt spekter af ældre, navngivne Aabenraa-borgere er på denne måde repræsenteret.

En række af de bevarede albums er i fin stand og typiske eksempler på datidens ofte meget fornemt udførte albums. Det gælder bl.a. det album, som redaktør Johs. Moldt modtog som afskedsgave, da han i 1875 fratrådte som redaktør af Dybbøl-Posten i Sønderborg. Med sin samling af portrætter af sønderjyder, der var fremtrædende $\mathrm{i}$ det nationale arbejde på den tid især $\mathrm{i}$ Als og Sundeved-området, er dette album også indholdsmæssigt af høj værdi. Familiesamlingerne omfatter i det hele taget adskillige nationalt fremtrædende personer og slægter, bl.a. H.P. Hanssen og familie, slægten Fink fra Stubbum og Hejls, landdagsmand Nis Nissen, redaktør, senere amtsskolekonsulent Nicolai Svendsen, seminarielærer Claus Eskildsen, Tønder, redaktør A. Svensson, Haderslev, læge Hans Lorenzen, Bov, der tillige var ivrig amatørfotograf og hvis negativsamling og film findes i samlingen. Aabenraa-slægter og -familier er stærkt repræsenteret med bl.a. slægterne Cornett, Fischer, Jacobsen. Hvor langt tilbage portrætterne når, ses bl.a. af den samling på 81 portrætter af indbyggere i Felsted sogn, som pastor M. Mørk Hansen fik i 1864, da han forlod sognet, og af den samling af portrætter af sognefogeder fra Aabenraaegnen, der stammer fra redaktor Frederik Fischer (d. 1871). Også for studiet af lokale fotografer og deres virksomhed helt tilbage fra 1850erne er portrætsamlingen og de mange albums af stor betydning. Der vil her kunne findes eksempler på fotografier optaget af næsten alle de fotografer, der har virket med bopæl og atelier i Nordslesvig før 1920.

Instituttet modtager ret ofte henvendelser fra slægtsforskere, der efterlyser fotografier af deres forfædre. Her må instituttet som regel melde pas. Dette hænger naturligvis sammen med, at det trods alt er meget tilfældigt, hvad der er afleveret af portrætsamlinger. Kun i de tilfælde, hvor et fotografarkiv er bevaret, kan der være håb om at finde et sådant portræt. Som det fremgår, er der imidlertid bevaret meget få fotografarkiver i Sønderjylland. 
Nationale og politiske forhold

I og med at et fotografi altid er et øjebliksbillede, kan det være vanskeligt at illustrere udviklingen over et bredt felt ved hjælp af fotografier. Oftest er det "begivenheder « der er foreviget, mens udvikling eller forandring eventuelt kan illustreres med en sammenstilling af forskellige billeder. De topografiske billeder er velegnede hertil, og de foreligger som nævnt i så rigelige mængder, at dette kan gøres for mange områders vedkommende.

Men også nationale og politiske forhold kan illustreres ved hjælp af billedsamlingen. Mange begivenheder som f.eks. afsløringer af mindesmærker, indvielser, møder, stævner osv. er foreviget. Mest berømt er måske billedet af den store folkemængde, forsamlet foran Folkehjem i Aabenraa den 17. nov. 1918, lyttende til H.P. Hanssens ord om, at en genforening med Danmark nu var nær. Det originale glasnegativ til billedet findes i fotograf Clausens samling. På samme måde findes der et enkelt billede af forsamlingen ved det sidste store danske årsmøde før Første Verdenskrig.

Mens tiden under Forste Verdenskrig kun i ret begræenset omfang er dokumenteret fotografisk for Nordslesvigs - hjemmefrontens vedkommende, findes der et omfattende materiale til belysning af forholdene ved fronten. Der blev fotograferet $\mathrm{i}$ ret betydeligt omfang ude ved fronterne, og tusindvis af billeder fandt vej hjem til Nordslesvig. Der er tale om gruppebilleder, hvor soldaterne er fotograferet f.eks. foran deres mere eller mindre velindrettede "boliger", der er billeder fra skyttegrave, af udbombede landsbyer og fra lazaretter, og både øst- og vestfront er repræsenteret.

De russiske krigsfanger i Nordslesvig blev i stort tal indkvarteret på landsdelens gårde, og der knyttedes mange steder gode og venskabelige kontakter til russerne. Det afspejler sig på mange billeder. I fotograf Th. Møllers negativsamling fra Løgumkloster findes et antal billeder fra den russiske krigsfangelejr og fra krigsfangekirkegården dér.

Tiden fra verdenskrigens afslutning i 1918 og frem til Genforeningen i 1920 var en urolig tid med mangel på næsten alt og derfor rig på demonstationer, smuglerier og uroligheder. Fra disse begivenheder findes der kun et meget begrænset antal fotografier, mens genforeningsåret til gengæld er særdeles righoldigt repræsenteret. Nævnes kan en række fremragende billeder optaget af forskellige, hovedsagelig danske pressefotografer. Af fotograf Clausen, Aabenraa, er bevaret ialt 89 glasnegativer med motiver fra genforeningsåret. Mange af dem blev publiceret som postkort og er bevaret $i$ en række albums, der har tilhørt bl.a. aabenraaere, som oplevede disse begivenheder. Også for mange af de glasnegativer fra genforeningstiden, som opbevares på Museet på Sønderborg slot, og hvoraf instituttet har kopier, gælder, at de blev mangfoldiggjort som postkort. 


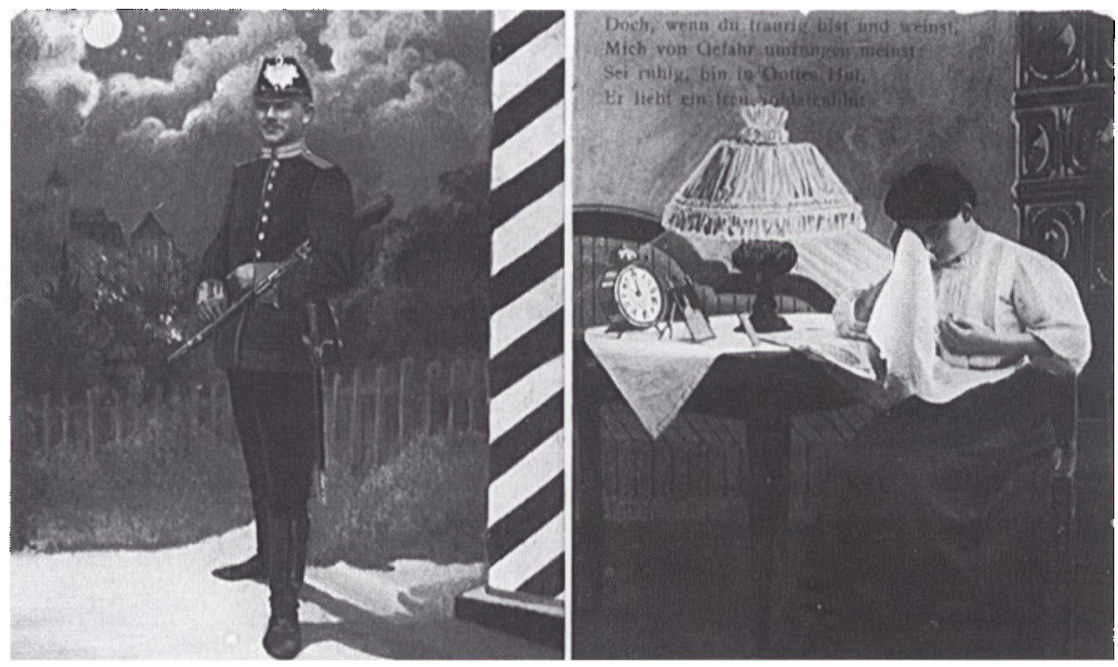

Alle nordslesvigske mand mätte for 1920 tjene det tyske kejserrige to år som soldater. Militarisk orden og disciplin, trofasthed mod kejser og "Vaterland" var normer, der ogsa afspejler sig pd postkort som dette. Den flotte og fadrelandstro soldat - endda en garder skal pigen derhjemme slet ikke vare bek ymret for: "Doch wenn du traurig bin und weinst, mich von Gefahr umrungen meinst: Sei ruhig, bin in Gottes Hut, Er liebt ein treu Soldatenblut.".

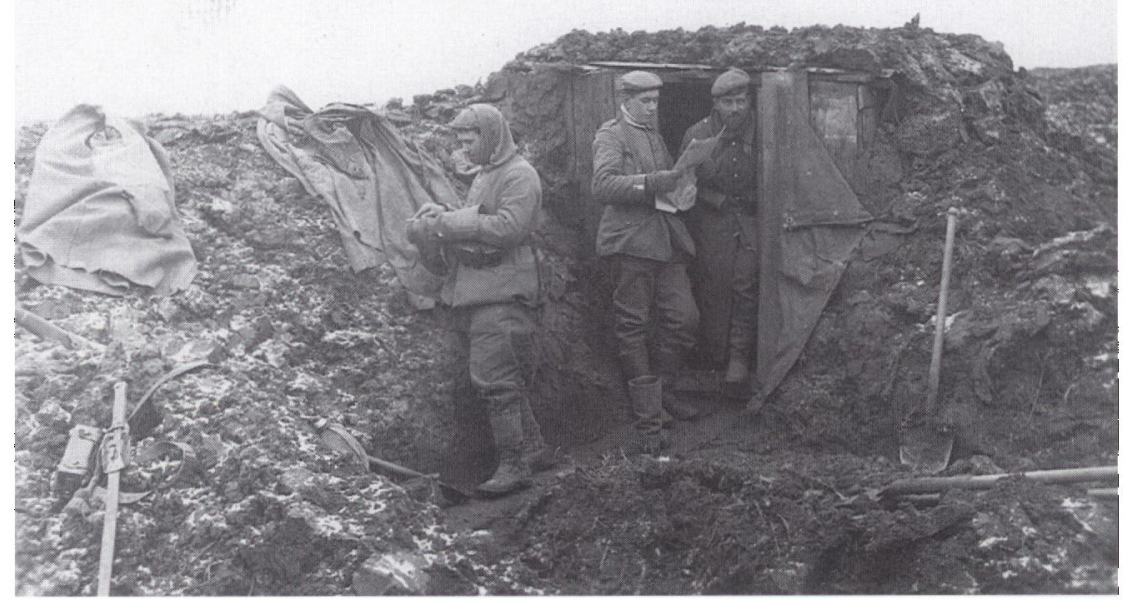

Forste Verdenskrig gjorde den militare virkelighed til et blodigt mareridt, som ogsa nordslesvigerne måtte gennemleve. Et fotografi, bragt hjem fra fronten, barer bagpd teksten "Indgang til Reservedakning bag Skyttegravenu. Det stammer fra familien Fink $i$ Stubbum og er kun et blandt instituttets mange billeder af den militare virkelighed under Forste Verdenskrig. 


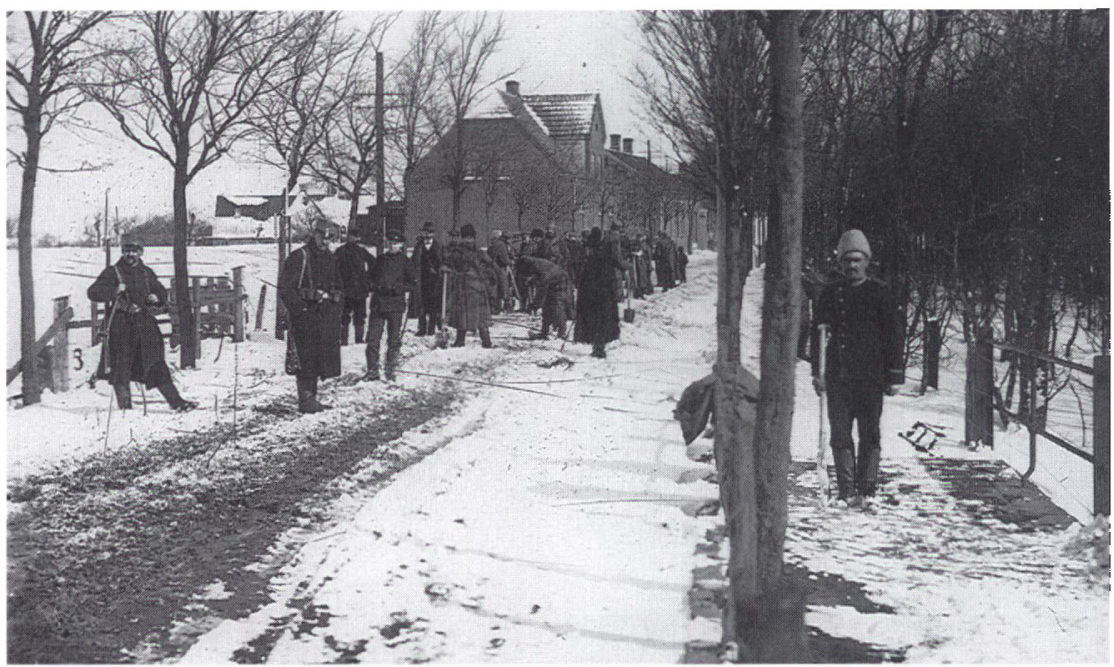

Russiske krigsfanger igang med snerydning $i$ Logumkloster, bevogtet af tyske soldater, indfanget vinteren 1916/17 eller 1917/18 af fotograf Th. Moller. Kopi af glasneg. nr. 68-83.

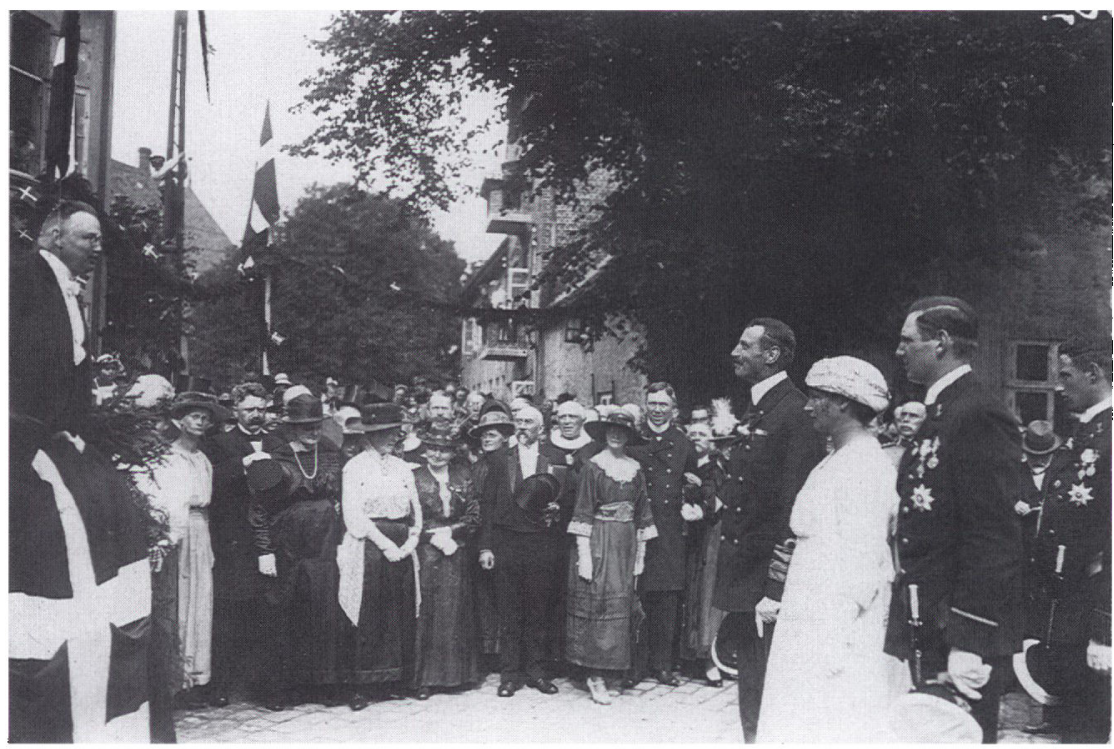

Pressefotograf Thv. Larsen, Berlingske Tidende er mester for dette fremragende billede fra Tonder den 12. juli 1920. Byens tysksindede borgmester byder fra en Dannebrog-smykket talerstol kongefamilien velkommen, mens byens festkladte borgerskab ser til i forste parket. Sarsaml. 307-28. 


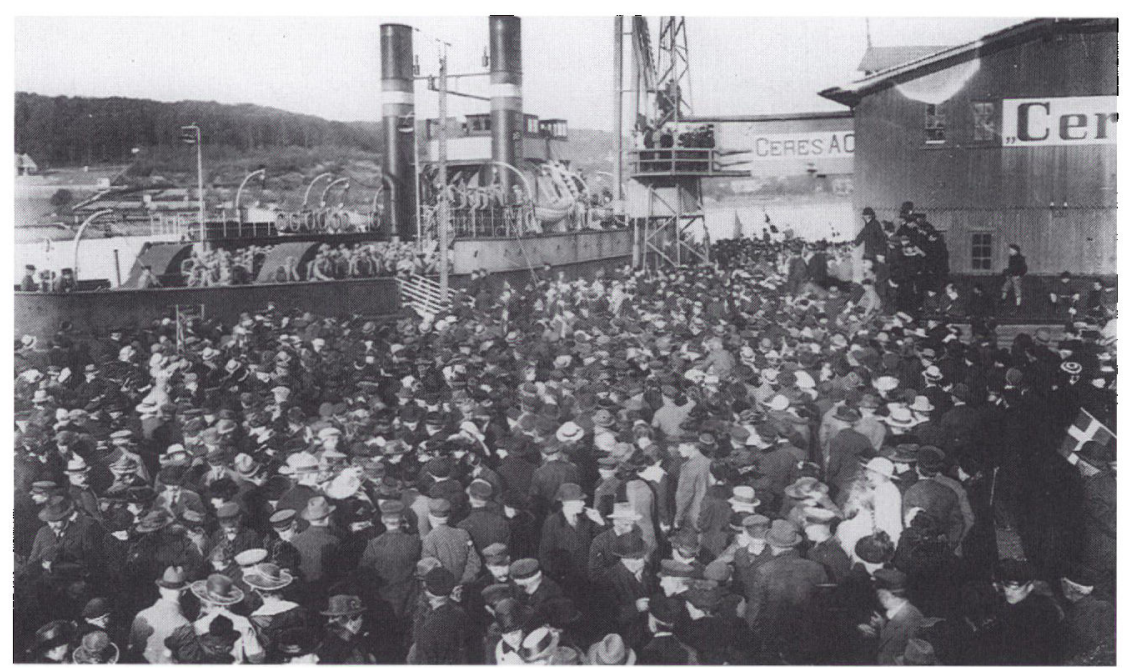

En af de store begivenheder i genforeningsåret var de danske soldaters ankomst den 5. maj 1920. Tusindvis af mennesker var modt op $i$ Haderslev, Aabenraa, Sonderborg og Tonder, da soldaterne ankom med tog eller med skib. Her er det fotograf Clausen, der har fyret et billede af, netop da fargen Marie har lagt til i Aabenraa. Glasneg. nr. 80-526 (13×18).

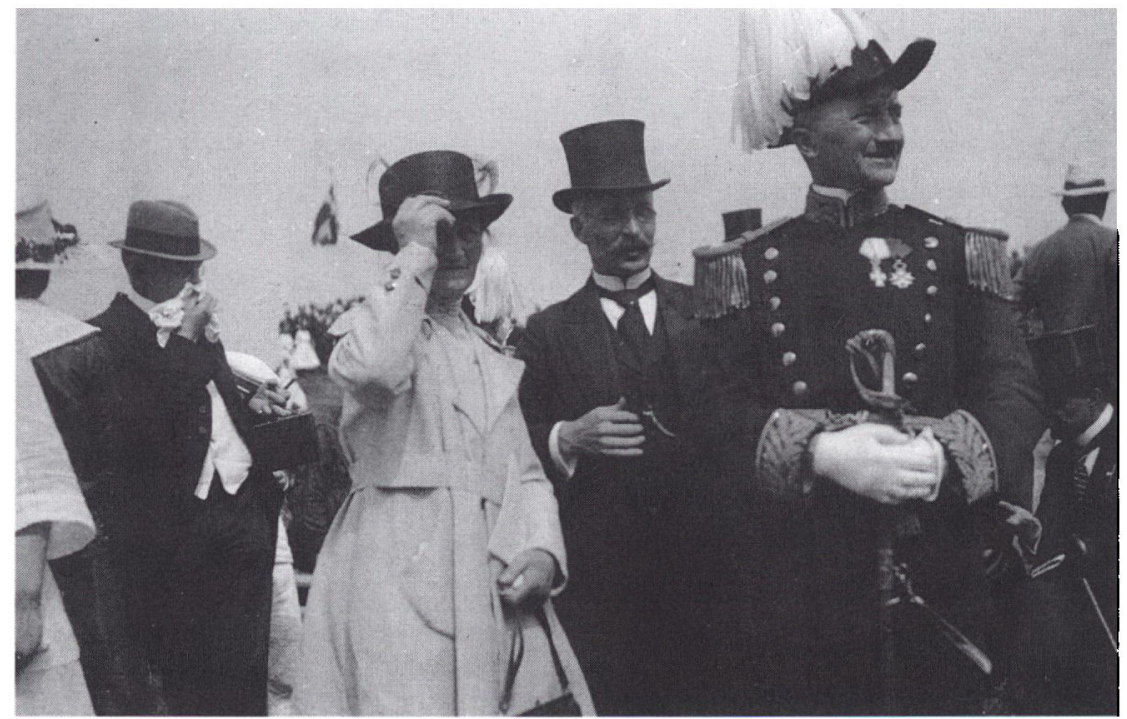

Familiesamlingerne eller de samlinger, som stammer fra en enkelt person, rummer meget ofte billeder af mere privat karakter, som regel taget af amatorfotografer. Det er ikke de mest kedelige billeder! Her er det et billede fra landdagsmand Nis Nissens samling. Nis Nissen er fotograferet $i$ Kongeskansen under Genforeningsfesten den II.juli 1920 sammen med Helene Hanssen, H. P. Hanssens hustru, og stiftamtmand Viggo Haarlov, Haderslev, alle i stiveste puds. 


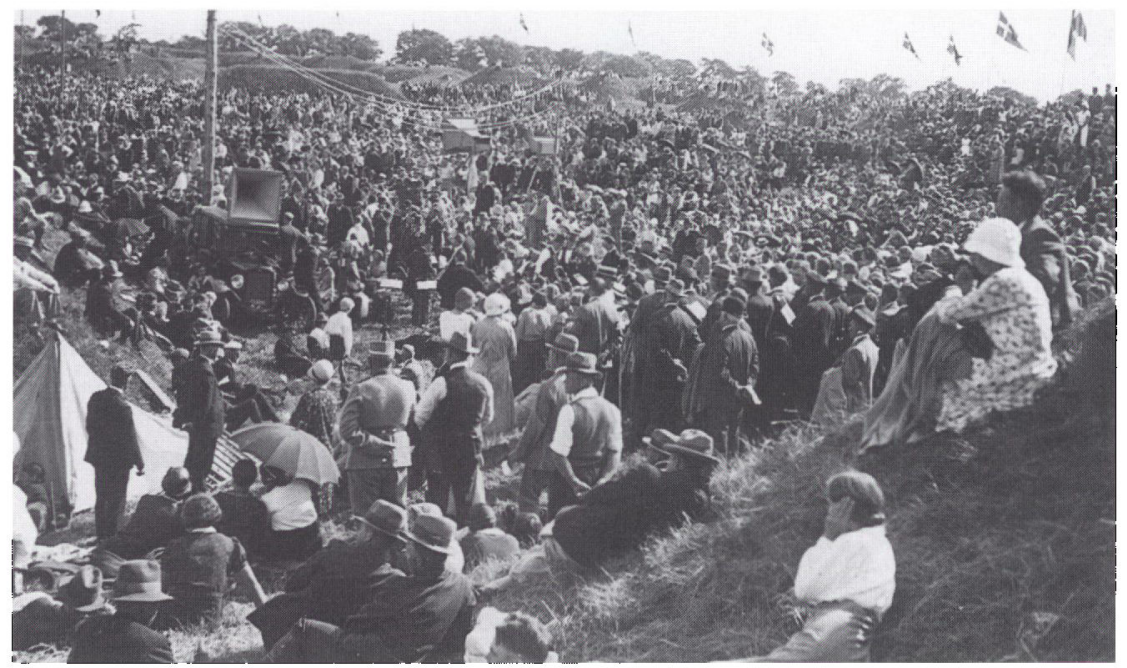

Det Unge Gransevarn var stiftet i 1933 til varn imod gransen fra 1920. At tilslutningen til Det Unge Gransevarn var stor, fremgår af dette amtorhillede fra det forste store stavne pä Dybbol den II.juni 1933. Sarsami. 301-(09, neg. 64-07-04.

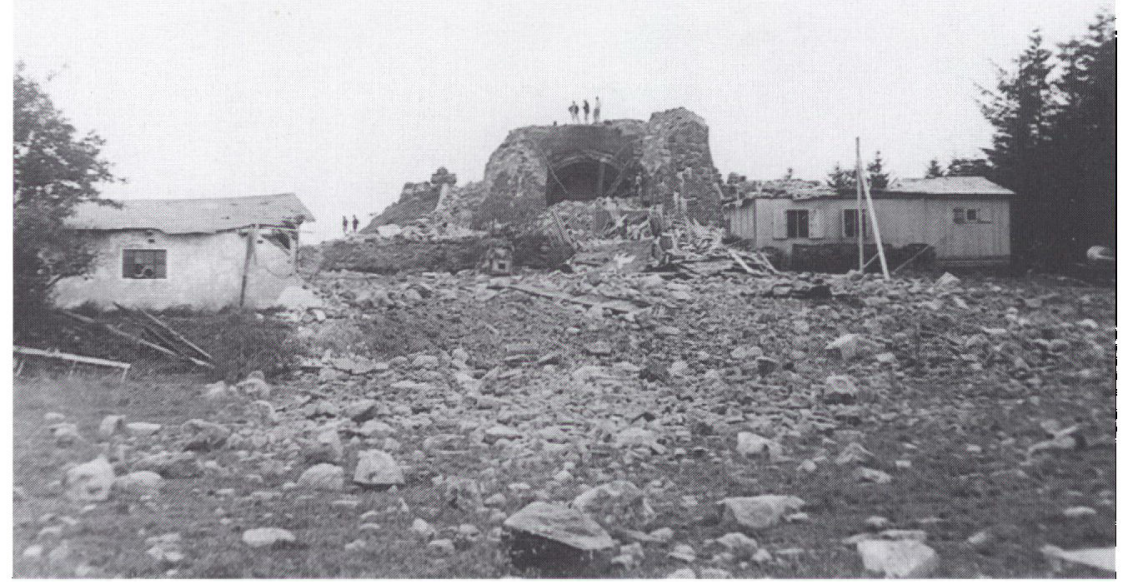

Knivsbjerg blev sprangt saf ukendte gerningsmand" 16. august 1945. Fotograf Th. Christesen fra Aabenraa var pd pletten og tog en rakke billeder her ses et af dem. Kun fundamentet af det store tärn var tilhage, resten var spredie murbrokker. Sarsaml. nr. 277-1388. 


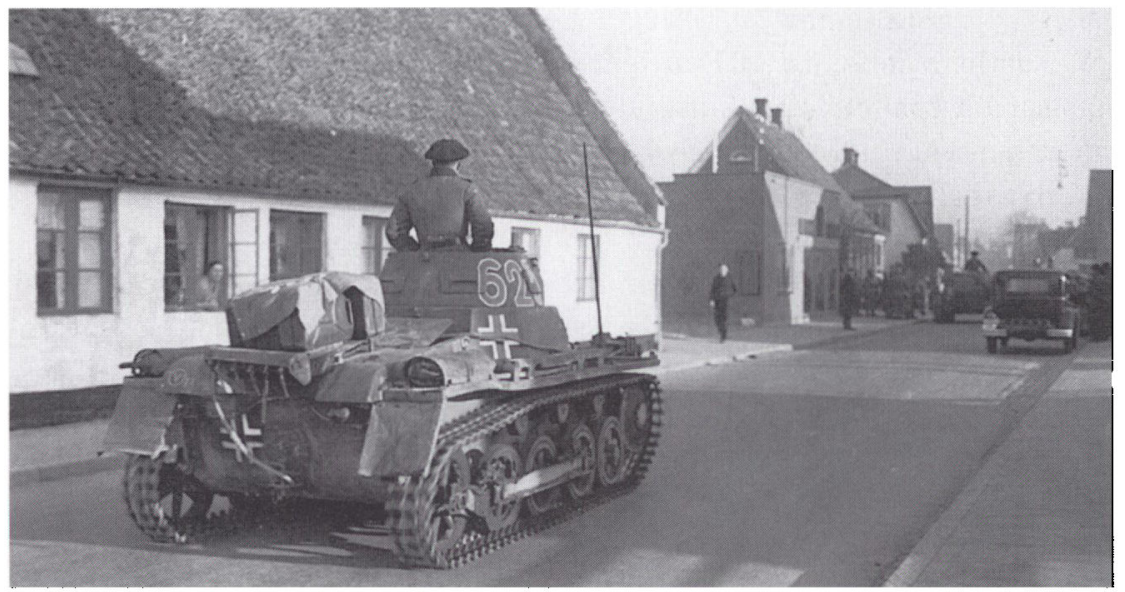

Den 9. april 1940 om morgenen var fotograf Th. Christesen tidligt pd henene. Danske soldater var găet $i$ stilling $i$ den sydlige udkant af Aahenraa. Christesen fotograferede irrigt los, og han og andre tilskuere overhorte advarsler og ordrer om at fjerne sig. Forst da der abnedes ild imod tyskerne fortrak de. Th. Christesen med et antal billeder af de danske soldater $i$ stilling. Pa hilledet her ruller tyske kampvone imod nord ad Sonderport, efter at skudvekslingen var slut. Th. Christesen fulgte dem gennem hele byen og var også senere pd dagen i Bjergskov plantage syd for hyen, hvor der ogsả var blevet kampet. Sarsuml. nr. 277-626.

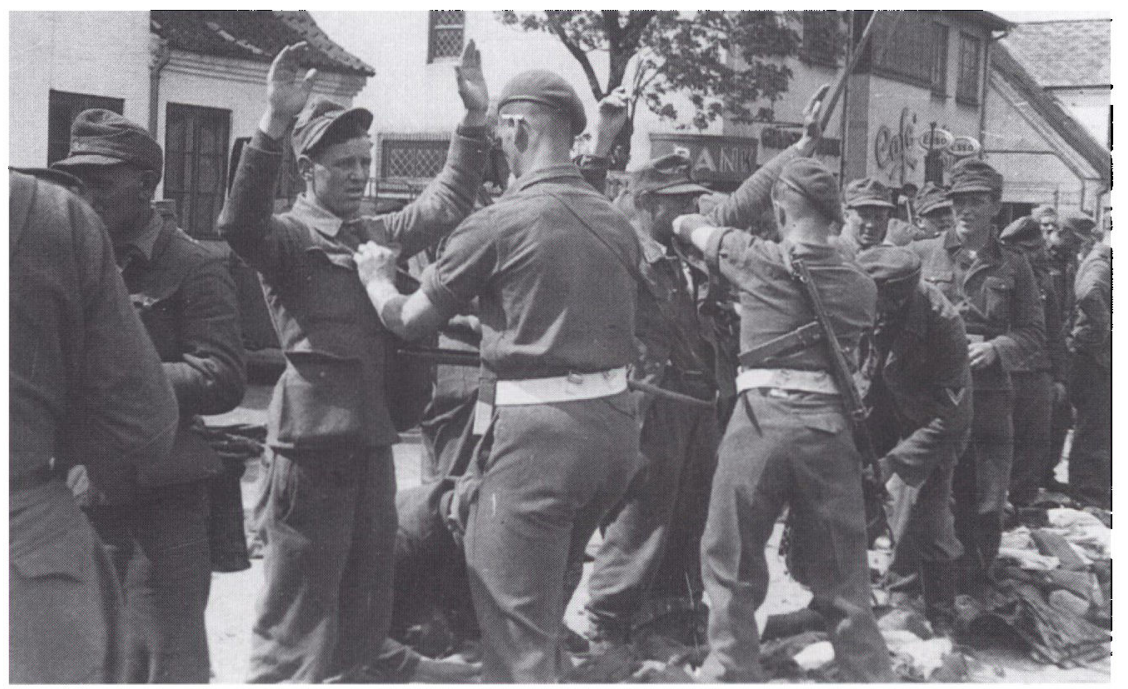

Den tyske varnemagts passage af gransen til Tyskland i tiden efter kapitulationen den 5. maj 1945 er veldokumenteret, ikke mindst takket vare fotograf Th. Christesens mange billeder fra gransen ved Krus$\dot{a}$, hwor han må have opholdt sig $i$ dagevis. De tyske soldater blev frataget alt, hvad de bragte med pd cykler og trakvogne. Her er reprasentanter for modstandsbevagelsen igang med undersogelserne. Sarsaml. 277-1192. 
En helt speciel samling af billeder fra Genforeningen er de ca. 300 amatørfotos, som blev indsamlet af Den sønderjyske Fond umiddelbart efter Genforeningen, og som nu indgår $i$ instituttets samlinger. Mange fulgte en opfordring om at indsende billeder, og selvom de fleste viser "de store begivenheder «, er det alligevel på en anden måde end de mere "officielle« billeder, som bl.a. pressefotograferne har taget.

Også for tiden efter 1920 gælder, at det er begivenhederne, som bedst lader sig illustrere med fotografier. Kongebesøgene er veldokumenterede og det samme gælder de store nationale stævner, som bl.a. blev arrangeret af Det Unge Grænseværn (DUG) fra $1933 \mathrm{og}$ frem, da det tyske pres på grænsen forstærkedes. Også for 1920erne og 1930erne er amatørfotografernes billeder et vigtigt islæt. Det gælder ikke mindst for det tyske mindretals aktiviteter før 1945. Til dokumentation heraf findes der et omfattende billedmateriale, og ikke mindst mindretallets gradvise nazificering fremgår heraf. Det er bl.a. billedmateriale, som blev konfiskeret i 1945, fjernet fra mindretallets »hovedkvarter« i Aabenraa, det såkaldte Dibbern-Haus, og dermed reddet for eftertiden. Men også en betydelig negativsamling fra en ung hjemmetysker belyser forholdene inden for mindretallet i 1930erne og under besættelsen.

lkke mindst hjemmetyskerne har fotograferet tyskernes besættelse af Danmark den 9. april 1940. Blandt instituttets værdifulde samlinger til belysning af besættelse og kapitulation må dog især nævnes Aabenraafotografen Th. Christesens. Han har fotograferet tyskernes indtog den 9.april og deres hjemvenden efter kapitulationen i maj 1945, hvor han i dagevis må have opholdt sig i Kruså. Nedstyrtninger og sabotagesprængninger kom også med på hans billeder. Han har efterladt sig et meget stort antal billeder samt negativer (24×36), der desværre er delvis uregistrerede, bl.a. på grund af manglende identifikation. Efter 1945 virkede han især som soldaterfotograf. Et meget stort antal soldatergruppebilleder fra kaserner i det meste af Jylland blev resultatet.

For tiden efter 1945 er det langt mere tilfældigt, hvad der er indgået $\mathrm{i}$ billedsamlingen også til illustration af den politiske og nationale udvikling. Det hænger nok for en stor dels vedkommende sammen med, at nyere, storre samlinger, bl.a. fotografsamlinger, endnu ikke er afleveret. Afleveringen af fotograf Holger Clausens fotografarkiv i 1989 - dækkende perioden ca. 1950-87 - illustrerer, hvordan mulighederne for samtidsdokumentation pludselig øges ganske betydeligt. Forhåbentligt vil tilsvarende fotografarkiver også andre steder i de kommende år finde vej til arkiverne.

Pressefotografier er en anden vigtig gruppe af billeder, som gerne skulle ind $\mathrm{i}$ arkiverne, og man må også håbe, at amatørfotografernes billeder og negativsamlinger i tide sikres for eftertiden. For der er næppe tvivl om, at det 
er i disse samlinger, vi fremover skal finde en stor del af den billedmæssige dokumentation af lokalsamfundets udvikling og af dets store og små begivenheder.

\section{Billedsamlingen og fremtiden}

Institut for Sønderjysk Lokalhistories muligheder for at følge den billedmæssige dokumentation af sønderjyder og Sønderjylland op til vor egen tid, vil nok i nogen grad begrænses af de mange lokalhistoriske arkiver, som er opstået $i$ de sidste ca. 20 år. Mange billeder og mange samlinger vil utvivlsomt finde vej hertil. Dette er af mindre betydning, da hovedsagen må være, at billederne bevares for eftertiden. Et samarbejde om affotografering af billeder - således som instituttet $\mathrm{i}$ øjeblikket praktiserer det med arkivet $\mathrm{i}$ Tinglev - vil dog råde bod på dette forhold.

Der vil dog fortsat være plads til og behov for instituttets billedsamling. Større foto- og negativsamlinger, der rækker ud over et snævert lokalområde, vil finde deres naturlige plads her, ligesom en formidling af den omfattende samling fortsat må være en vigtig opgave. Manglende ressourcer vil forhåbentlig ikke sætte alt for snævre grænser for arbejdet.

\section{BILAG}

Fortegnelse over fotografarkiver og negativsamlinger $i$ Sonderjylland

For fotografernes vedkommende henvises til Bjørn Ochsner: Fotografer $\mathrm{j}$ og fra Danmark til og med år 1920, 2. udg., 1986. Hvor intet andet bemærkes, er negativerne på glas.

\section{Haderslev Museum}

Peter K. Lund (f. 1884), fotograf, Haderslev, fra 1920 (j. nr. 2550, Ochsner s. 532). ca. 35.600 nega-

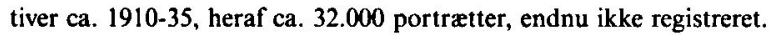

Johan Henrik Iversen (1890erne) og Jørgen Hesselberg, fotografer Sommersted, 1898-ca. 1950 (j.nr. 2190, Ochsner s. 408 og 384). 13155 negativer ca. 1900-?, ca. halvdelen portrætter; reg. på PCfile.

Charles L.Sundbøll (f. 1885), fotograf, Hoptrup fra ca. 1929 (j. nr. 1042, Ochsner s. 786). 9771 negativer ca. 1930?, hovedsagelig bygninger; reg.på PC- file. Reneg. og positivfilm i Institut for Sønderjysk Lokalhistorie.

Richard A. Deerz (f. 1890), Haderslev, fra 1911 (j. nr. 1284,Ochsner s. 244)). 3575 negativer, nasten kun portrætter; reg. på PC-file.

Andreas Andresen (1884-1971), fotograf, Haderslev, 1906-51 (j. nr. 2552, Ochsner s. 126). ca. 100 glasneg. og 300 planfilm, ingen portratter, ikke reg.

Car] N. Rudolph (1880-1973), fotograf, Haderslev, 1909-52 (j. nr. 2525, Ochsner, s. 724) ca. 300 negativer, kun få portrætter, ikke reg.

Kai Arling, fotograf, Haderslev, efter 1920 (j. nr. 2196, fader: Ochsner s. 129). ca. 300 negativer, de fleste portrætter kasseret, ikke reg.

N. H. Nielsen (uden j. nr., proveniens usikker). 9000 negativer, ikke reg. 
Viborg og forgæengere, Vamdrup (nr. h 6562). ca. 30.000 negativer, deponeret på Museet på Koldinghus 1979.

Peter Henningsen (1872-1949), urmager, Storegade, Haderslev. 837 negativer, Haderslev og omegn, ikke reg.

C. M. Lund (1869-1941), museumsinspektør, Haderslev. ca. 4000 negativer, landskaber og oldtidsminder, ikke reg., men de fleste registreret som positiver.

\section{Tonder Museum}

Verein Baupflege Kreis Tondern (før 1914). ca. 1250 negativer, bygninger, samlingen delt, således at alle negativer med motiver syd for 1920-gransen er afleveret til et hjemstavnsmuseum i Niebøl (nord for grænsen: ca. 300 stk), trykt fortegnelse til og med nr. 930.

\section{Museet pd Sinderhorg slot}

Robert Buchard, Sønderborg. 328 ruller film $(24 \times 36 \mathrm{~mm}), 119$ ruller planfilm samt diverse store negativer, personer, begivenheder, delvis af privat karakter, 1942-53, delvis registreret, en del uidentificeret.

Museets egen samling af glasnegativer. ca. 2500 negativer, forskellig proveniens, bl.a. egne optagelser (museumsinspektør Jens Raben, bl.a. udgravninger, oldtidsminder), dels indkøb, dels gaver. Mange negativer fra genforeningsbegivenhederne i 1920. Registreret.

\section{Institut for Sonderjysk Lokalhistorie, Aabenraa}

Peter Clausen (1885-1952), fotograf, Aabenraa, 1908-49 (Ochsner s. 233). Holger Clausen (1921-91), fotograf, Aabenraa, 1949- ca. 1988 (saml. nr. $80 \mathrm{og} 81$ ). Rester af fotograf Peter Clausens samling 1908-49 samt sønnen Holger Clausens samling 1950-ca.1988, ialt ca. 80.000 numre. registreret, Holger Clausens ved fotografens eget kartotek.

Laurids Matthiesen, fotograf, Hejer, 1893-1953 (saml. nr. 73,Ochsner s. 553). ca. 21.000 numre, bestillingsprotokoller bevaret.

Carl C. Biehl (1872-1950), postkortfabrikant, Gråsten ca. 1905-1940 (saml. nr. 74). ialt ca. 5000 glasnegativer og ca. 5000 stk planfilm, udelukkende topografiske motiver, registreret.

L. v. Münchow, fotograf, Aabenraa. 404 negativer 1932-47, hovedsagelig portrætter (saml. 79), 212 stk. planfilm 1940-47, (saml. 52). stor samling rullefilm, uordnet, uden protokoller, hovedsagelig portratter.

Th. Christesen (1883-1958). fotograf. Aabenraa fra ca. 1920. 168 negativer 1928-41 (saml. nr. 69), 146 stk planfilm 1939, 1945 og udat. (saml. nr. 51), registreret; stor samling rullefilm $(24 \times 36$ $\mathrm{mm}$ ) uordnet, uden protokoller, heraf udgør soldaterportrætter og -gruppebilleder fra sonderjyske garnisoner ca. 1948-57 en vesentlig del, positiver heraf er bevaret. Af Th. Christesen er bevaret en meget stor samling positiver, hovedsagelig med motiver fra besættelsestiden, registreret (saml. 277).

A. Martinsen, boghandler og fotograf, Højer. fra ca. 1918,(Ochsner s. 551). 224 negativer (saml. nr. 70 ), 287 plannegativer $6 \times 6 \mathrm{~cm}$ (saml. $\mathrm{nr}$. 13), hovedsagelig topografiske motiver, registreret.

Theodor Moller (1861-1941), boghandler og fotograf, Logumkloster, fra ca. 1900. 125 negativer for 1920, hovedsagelig topografiske motiver, registreret (saml. $\mathrm{nr}, 68$ ).

Wilhelm Schützsack (1870-1947), fotograf, Aabenraa, Haderslev, Gram, Tinglev, (Ochsner s. 755). ca. 990 glasneg. alle topografiske, hovedsagelig med motiver fra Nordals, registreret (saml. nr. 72).

Richard Reich (død 1952), fotograf, Augustenborg (Ochsner s. 706). 1076 negativer, hovedsagelig topografiske billeder samt gruppebilleder, før 1920, delvis identificeret, registreret (saml. nr. 78). Ochsner oplyser, at Nationalmuseet har ca. 10.000 af Reichs plader fra 1914-16),

Ukendt fotograf fra Logumkloster eller Tonder, 2120 negativer 1951-54, hovedsagelig portratter, uden identifikation, ikke registreret.

P. Ingwersen, fotograf, Gråsten, ca. 300 negativer 1952-54, hovedsagelig gruppebilleder. identificeret. registreret (saml. nr. 84).

Theodor Voswinkel (d. 1946), læge, Rømø, 253 negativer, topografiske motiver, enkelte portratter. Rømø 1905-21, registreret (saml. nr. 67). 
H.C. Davidsen (1876-1962), godsforvalter på Schackenborg, 175 negativer, topografiske motiver, enkelte portrætter, Møgeltønder og omegn 1897-1936, registreret (saml. nr. 69).

Schackenborg, optagelser af lensgreve Hans Schack (1852-1905). 570 negativer, fra Schackenborg bl.a. interiørs og Møgeltønder og omegn, private optagelser (nogle formodentlig af datteren, komtesse Agnes), bl.a. fra genforeningen 1920, delvis registreret (saml. nr. 66).

Th. Münster, bogbinder, Haderslev. 91 negativer, topografiske motiver, registreret (saml, nr. 75).

Scharbert (?) fotograf, Aabenraa. 479 negativer, topografiske motiver fra Sønderjylland, samt forskellige dele af Danmark, brugt som forlæg for postkort udgivet af A.M.Lund, Haderslev, ca. 1930, registreret (saml, nr. 86). 